\title{
喉頭ストロボグラフィーによる声帯振動の解析 一解析機能の改良一
}

\author{
磯 貝 豊 \\ Analysis of the Vocal Fold Vibration \\ by the Laryngo-strobography \\ -Improvements of the Analytic Function-

\section{Yutaka Isogai}

Larygo-strobography is a newly developed analytic method for quantitative analysis by strobovideography. It's characteristic point is that it can arrange not only in time series all of the vibratory periods of arbitrarily sectioned images of the vocal folds as a single still image, but also superimpose voice-related signals (the voice signal, EGG, subglottal pressure, etc.,) synchronized to the trigger pulse of the laryngo-stroboscope.

The five improvements of the analytic function mentioned below are added to the previous paper.

(1)Three parameters of open quotient, speed quotient, and speed index can be displayed by the automatic calculation from the three numbers of the fields of the opening phase, closing phase, and closed phase during the one vibratory cycle of the vocal fold.

(2) The fundamental frequency of voice synchronized to the each analytic field can be displayed by the automatic count of the time interval between the trigger pulses of the laryngostroboscope.

(3) Three analytic axes can be selected simultaneously.

(4) The analytic axis of the artificially shifted field due to the scope-folding-hand tremor can be corrected automaically by the semi-automatic detection of the boundary between the non-vibratory false vocal fold and the vocal fold.

(5)The differences of the brightness among the each fields due to the difference of the count of the strobo-light radiation can be corrected automatically.

Key words：喉頭ストロボグラフィー（Laryngo-strobography），喉頭ストロボグラム (Strobogram), 喉頭ストロボスコピー (Laryngo-stroboscopy), 声帯振動解析 (Analysis of the vocal fold vibration)

1.は じめに

ストロボモーションアナライザー（図 1 ) は，喉頭スト ロボスコピー時に, 喉頭ストロボコープのストロボ発光信 号に同期した位相における声帯振動画像と音声関連信号 （音声信号・EGG 信号・声門下圧信号など）の両者を同時 に合成記録することによって, 声帯振動様式だけでなく音 声関連信号との位相関係も簡単かつ定量的に解析すること を目的として, フローベルならびに永島医科器械と共同開 発した装置である。

われわれは，ストロボモーションアナライザーを用いた 解析方法を喉頭ストロボグラフィー ${ }^{1)}$ と仮称しているが, とりわけ，振動声帯の解析目的部位（声帯膜様部中央など） を直交座標方式による解析軸によって指定し, 指定部位の 画像だけを field by fieldに継時的に128フィールド分 $(64$ フレーム, 約 2 秒間分：ストロボスコープの見かけの振動

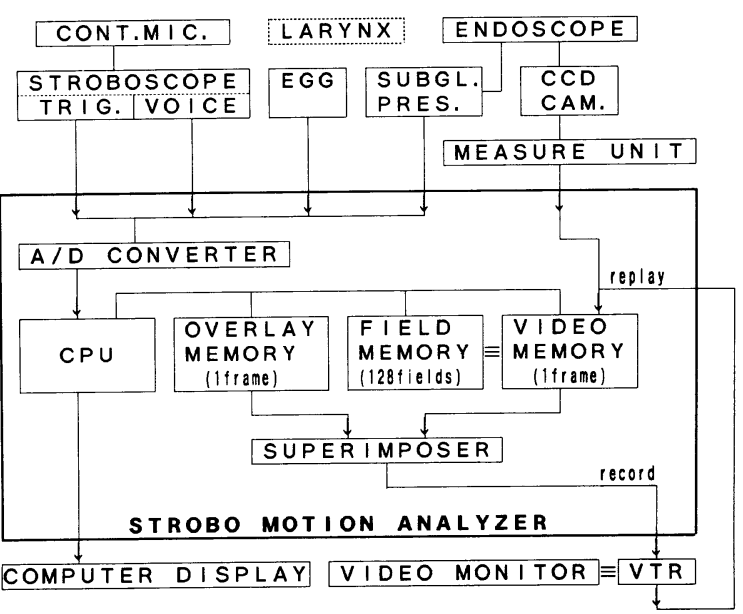

図 1 ストロボモーションアナライザーのブロック図 
周波数が $1 \mathrm{~Hz}$ の場合は約 2 振動周期分）連結表示する喉 頭ストロボグラムは, 解析部位の全周期にわたる声带振動 様式のみならず，これに同期した音声関連信号もあわせて 1 枚の画像として合成表示できるので, 振動周期全体にわ たる両者の関係を一目瞭然に把握できるという利点がある.

今回, ストロボモーションアナライザーの解析機能をさ らに向上させ, 下記の改良を行ったので報告する. (1)スト ロボグラム上の 2 本の解析フィールド指定カーソルに対応 するフィールド番号をもとに声帯振動開大期・閉小期・閉 鎖期の相対的な時間（フィールド数）を計測し,この值か ら, OPEN QUOTIENT, SPEED QUOTIENT, SPEED INDEX の開閉運動に関するパラメータ ${ }^{2)}$ を自動計算表示 するようにした。(2)それぞれの解析フィールドにおける音 声の基本周波数と, 2 本の解析フィールド指定カーソル間 の平均基本周波数を表示した。 (3)解析部位を, 声帯前部と 中央部と後部など, 合計 3 ケ所まで同時に指定可能にした. (4)喉頭鏡の手ぶれなどによって声帯振動解析軸の補正を行 う時, より容易で確実な補正を可能にするため, 前後のフィー ルドの解析軸をスーパーインポーズすることにした. また， 仮声帯との境界を自動検出することによって, 左右方向軸 のぶれの自動補正を可能にした. (5)ストロボ発光回数の違 いによる, 各フィールド間の輝度のばらつきを補整できる ようにした。

\section{2. 方法ならびに結果}

(1)開閉運動に関するパラメータの自動表示と(2)音声の基 本周波数の表示について (図 2 図 3 ).

図 2 は, ストロボモーションアナライザーの画像メモリ に取り込んだ, 右声帯囊胞症例の比較的大声での発声条件 における OPENED PHASEのフィールド画像である.

喉頭ストロボグラムの声帯振動画像は, 声帯前後軸（A$\mathrm{P}$ 線）に直交する 2 本の解析軸（B軸）で囲まれた範囲の 画像だけをフィールド順に連結表示するものである.

解析対象範囲を指定する方法は, 声帯前後軸に相当する $\mathrm{A}-\mathrm{P}$ 線の A 端と B 端とをそれぞれ独立に，あるいは A-P 線全体を左右に移動して声带前後軸の方向を指定し, つい で，A-P 線に直交するB 線（解析軸に相当する）を， A-P 線上を上下に移動させることによって指定すると，B 線に 囲まれた画像区間だけが解析対象画像範囲として表示され る方式になっている.

喉頭鏡の手ぶれが大きい場合には，各フィールドごとに, 声帯前後軸と解析軸の両者を微調整する必要が生じるが, 喉頭鏡の手ぶれが少ない場合には, 最初の第 1 フィールド 画像の声帯前後軸と解析軸を設定すれば，以降のフィール ドの声帯前後軸と解析軸の補正は不要である.

図 2 の最下段に表示してある 3 段の白線欄（」）の左側 の欄は, このフィールド画像のフィールド番号の位相に同 期した音声関連信号 (音声信号, EGG 信号, 声門下圧信 号）の数值情報をアナログ画像信号に変換したものを声帯 振動画像にスーパーインポーズ（オーバーレイ）したもの
である。

右欄は, 今回, 新たに追加した機能で, 音声基本周波数 を3桁（３段）で表示したものである.

図 3 は, 図 2 のストロボグラムである.このストロボグ ラムは, 喉頭鏡の手ぶれがほとんど無い画像であるので, 解析軸の設定は最初のフィールド画像だけである.

左欄は, 先に指定した解析範囲の声帯振動画像だけをフィー ルド順に上から下に連結表示したものであり，中央は EGG 波形を，右欄には音声波形を表示したものである.

$\mathrm{EGG}$ 波形と音声波形が 2 周期にわたって定常的である ので,この間の声带振動は定常的振動と判定できる.

声帯振動画像からは, この間の声帯振動が, 両側声带の いわゆる下唇部が接着する閉鎖期の開始の位置 $(\leftarrow)$ と, 閉鎖期間中に両側のいわゆる上唇部が接着する位置 $(\rightarrow)$ とがずれており，上唇部の接着位置（）が下唇部の接着 位置（ヶ）より左側（健側側）に変位していることがわか る。

また, EGG 波形からは, 開大期の直前から直後の位相 にかけて, 小さなノッチが形成されており，この位相で声 門の電気抵抗に微小な変化があることが推測される.

画面の最下段には, 今回新たに追加した解析結果が表示 してある。

2 本の解析フィールド指定カーソル, 線 A (黄色線) と 線 B (緑色線) の右隣には, 各線が位置するフィールド番 号を表示してあり, 線 A は第62番フィールド, 線 B は第 75 番フィールドに位置していることを示している。

その右隣には, A, B両線のフィールド番号の位相にお

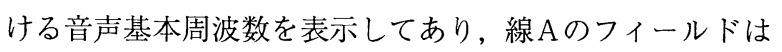
$138 \mathrm{~Hz}$, 線 Bのフィールドは $145 \mathrm{~Hz}$ である。その右隣には， 線 $\mathrm{A}$ と線 $\mathrm{B}$ のフールド間の平均基本周波数が表示してあ り, 本図では $147 \mathrm{~Hz}$ である.

さらに右隣には, 今回新たに追加した, 開閉運動に関す るパラメータ, OQ (OPEN QUOTIENT : 開放時間率), SQ（SPEED QUOTIENT：開閉速度率), SI（SPEED INDEX : 開閉速度指数) を自動計算表示してある.

各パラメータの值は, 左欄の声帯振動画像フィールド間 を, 線 $\mathrm{A}$ と線 B を移動させて開大期, 閉小期, 閉鎖期の各 振動周期を指定し, その間のフィールド数（線Aのフィー ルド番号と線 B フィールド番号との差分) を求めることに よって, $\mathrm{OQ}$ (開放期のフィールド数 $/ 1$ 周期のフィール ド数), SQ（開大期のフィールド数／閉小期のフィールド 数), SI（開大期のフィールド数一閉小期のフィールド 数 /開大期のフィールド数+閉小期のフィールド数) を自 動計算によって求めたものであり, この声帯振動は, $\mathrm{OQ}=$ $0.4, \mathrm{SQ}=1.2, \mathrm{SI}=0.1$ である.

最右欄には, 開大期を指定した時の線 Aのフィールド番 号62と線Bのフィールド番号75が表示されている.

(3)解析対象部位の増設について（図 4〜図 5 ).

今回さらに, 声帯前後軸に直行する解析対象部位を 3 ケ 


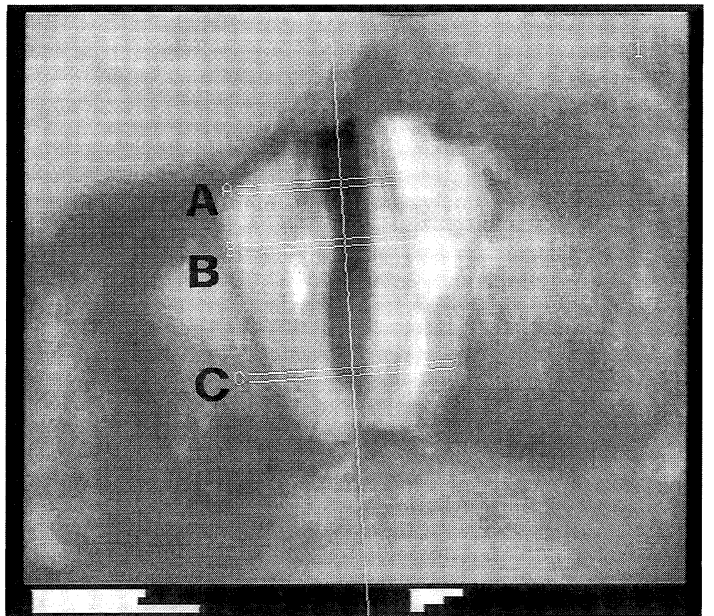

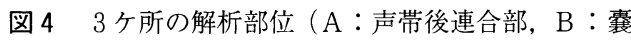
胞部, C : 前連合部).

所まで指定可能にした.

図 4 は 3 ケ所の解析部位 ( A : 声帯後連合部, B : 輁胞 部, C : 前連合部) を示し, 図 5 は, 図 4 の線 A, B, C の部位の声帯振動画像だけを左から順番に並列表示したス トロボグラムである.

開大期の開始の位相が，A，B，C間でずれていること がわかる。

(4)喉頭鏡の手ぶれの自動補正について（図 6～図14). 喉頭鏡の手ぶれが小さい図 3 のような振動周期では, 声 帯振動の前後軸と解析軸の設定は最初の第 1 フィールドだ けですむが，喉頭鏡の手ぶれが大きい場合には，各フィー ルドごとに声带前後軸と解析軸の補正が必要となる.

図 6 は，喉頭鏡の手ぶれが大きい周期のストロボグラム であり, 声带前後軸と解析軸の設定は最初の第 1 フィール ドでしか行っていない.

左欄の声帯振動画像でわかるように，動画再生で見ると 振動していない仮声帯と声帯との境界部（）が手ぶれに よって正弦波状に摇れてしまっている.

図6のようなケースでは，手ぶれによる声帯前後軸と解 析軸のぶれの補正を全フィールドにわたって順次行う必要 がある。

しかし，手ぶれの影響が主に水平方向だけの場合には， 声带前後軸の補正はさほど重要でなく，解析軸の左右方向 (水平方向)の補正だけを重点的に行えばよいので, 非振 動部位（仮声帯と声帯との境界部）を自動認識させること によって，水平方向についてだけ自動補正することが可能 となる。

図 7 は, 図 6 の最初の第 1 フィールド画像の解析軸上の 輝度信号分布を, R (赤色), $\mathrm{G}$ (緑色), B (青色), $\mathrm{W}$ (白色) $(2 \mathrm{R}+\mathrm{G}+\mathrm{B} / 4)$ で表示したものである.

この輝度信号分布波形を左端から自動掃引儿，画素数 3 ドット分以上連続して輝度が上昇している部分を輝度上昇

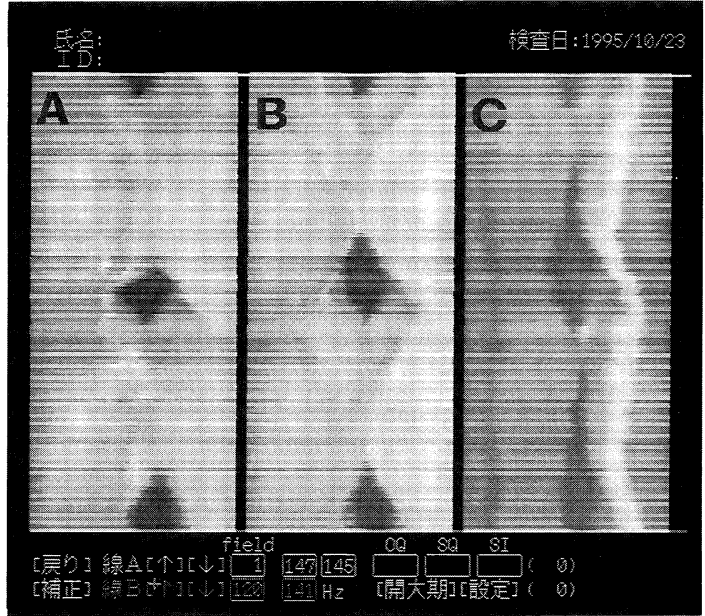

図 5 図 4 の線 $\mathrm{A}, \mathrm{B}, \mathrm{C}$ の声帯振動画像だけを左か ら順番に並列表示したストロボグラム。

部，3ドット分以上連続して輝度が下降している部分を輝 度下降部とし，下降部から上昇部に転じる部分（谷底部） を自動認識のノッチ点とする。

最初のフィールド画像において，まず目認によって，左 側の非振動部分（】）と右側の非振動部分（†）のノッチ の位置を指定し，さらに，どちら側のノッチを非振動部の 基準とするか（この場合は左側）を指定する。この位置を 解析軸上の基準位置とし，次のフィールドから順次，非振 動部の位置を自動的に同定する。

すなわち，次のフィールド画像は，前のフィールド画像 の基準位置から \pm 15 ドット以内の範囲のノッチ部分を自動 検出し，最寄りのノッチ部分を同じ基準位置として自動判 定する。この範囲内にノッチ部分が検出されない場合には, 前のフィールド画像の基準位置と同じ位置に自動設定する.

この方式で非振動部の位置を水平方向についてだけ自動 補正した結果が図8である. 左端の非振動部分（ $\rightarrow$. 仮声 帯と声帯との境界部）が縦に一列に並んで，きれいに自動 補正されていることがわかる.

しかし，この方式でも，ノッチ部分が極めて小さい場合 は自動検出が困難なフィールド個所も生じる.

図 9 は，図 6 とは異なる振動周期に扔ける，解析軸の補 正無しのストロボグラムで, 左端の非振動部分 $(\rightarrow$. 仮声 帯と声帯との境界部) が手ぶれによって不規則に摇らいで いる．図10はその第 2 フィールド画像の解析軸上の輝度信 号分布波形であるが，基準点とした左側のノッチ（】）の 振幅が極めて小さいことがわかる.

そのため, 自動補正の結果（図11）が一部（）で誤認 されてしまっている.

このようなケースのために，目認（手動）による簡単な 追加補正法も考案した。

図12に示したように, 目認によって, 非振動部分の位置 （仮声帯と声帯との境界部. $\rightarrow の$ 白点部）をまず基準点と して指定し，次いで，この基準点の位置に一致させるべき 


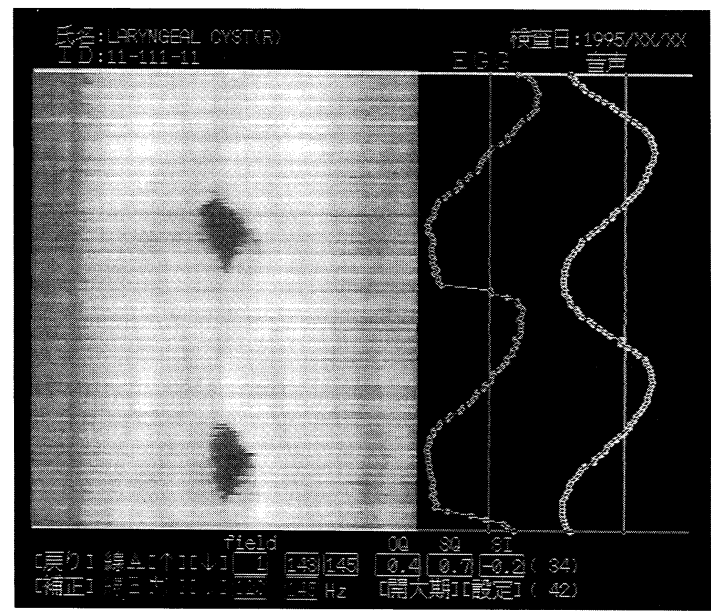

図15 各フィールド画像間の画面の明るさ (輝度) の ばらつきを明るいフィールドの輝度に合わせて 補整した結果.

補正対象フィールドの位置（†の十記号部）を指定すると， 十の位置を基準点の白点部の位置まで自動的に移動するよ うにした。

その結果を図13に示す。誤認された非振動部の位置が基 準点の位置 $(\rightarrow)$ に適正に補正されており，全周期にわたっ て完全に手動（マニュアル）で解析軸の補正を行った図 14 とほほ同じ結果がえられている.

(5)各フィールド画像間の画面の明るさ (輝度) のばらつ きの補整について (図15).

最後に，ストロボ発光回数の違いによる各フィールド画 像間における輝度のばらつきの補正について述べる.

補正方法として, 各フィールドにおける共通部位（仮声 帯と声帯との非振動境界部) の輝度を, 画面全体の明るさ （輝度）の基準とするフィールド画像の輝度に合わせる方 法をとった。

この方式によって, 図14のストロボグラムを補正した結 果が図15である.

極端に暗いフィールド画像部分が基準フィールド画像の 明るさに合わせて, ストロボグラム全体が明るい輝度に補 正されていることがわかる.
3. 考

\section{察}

喉頭ストロボスコピー，とりわけ，その所見をVTRに ビデオ記録する喉頭ストロボビデオグラフィーは，音声障 害の原因を声帯振動の異常と関連づけて解明する上で不可 欠の方法である。

しかしながら，喉頭ストロボビデオグラフィーによって も, 記録したビデオ画像の再生だけでは，定量的解析に限 界がある。

著者は，喉頭ストロボビデオグラフィーのより定量的な 解析を目的として喉頭ストロボモーションアナライザーを 開発し，その解析方法を喉頭ストロボグラフィー ${ }^{1)}$ と仮称 しているが, 本稿では, その解析機能の改良について報告 した.

今回の改良により，開閉運動に関するパラメータと音声 基本周波数の解析が可能となり，さらに，喉頭鏡の手ぶれ による解析軸の自動補正も簡単かつ容易となった。

しかしながら，解析軸の自動補正に関しては，(1)解析軸 の補正が水平方向に限られること，(2)非振動部分の基準点 の輝度変化が小さい場合には，誤認による自動補正ミスが 起こりやすいことなどの問題点が未解決であり，今後の更 なる検討が必要である.

\section{謝 辞}

本研究に際し，多大なご協力をいただきました永島医科 器械株式会社石田康裕氏，ならびに，フローベル株式会社 山田道雄氏，小田島伸寿氏，星 幸一氏の各位に感謝いた します。

本論文の要旨は, 第 7 回日本喉頭科学会において報告し た。

\section{参 考 文 献}

1）磯貝 豊：Strobographyによる喉頭機能検査．喉 頭 $6: 91 \sim 96,1994$.

2）平野 実：声帯の振動状態に関する検査。声の検査 法 (第 1 版), (日本音声言語医学会編) 79～87, 医 歯薬出版株式会社, 東京, 1979.

別刷請求先 干160 東京都新宿区信濃町9-2 東京電力病院耳鼻咽喉科 磯貝 豊 


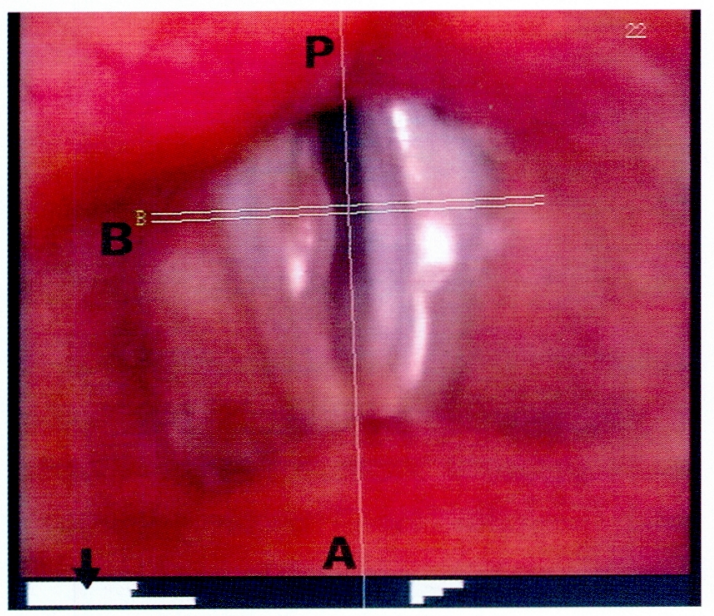

図 2 OPENED PHASEのフィールド画像(右声 带霊胞). A-P 線は声带前後軸, B 線は A-P 線に直交する解析軸.

最下の 3 段の白線欄（Џ）は，このフィールド 画像に同期した音声関連信号（音声信号， EGG 信号, 声門下圧信号)（左欄）と音声基本 周波数 (右欄) をアナログ画像信号に変換して オーバーレイしたもの.

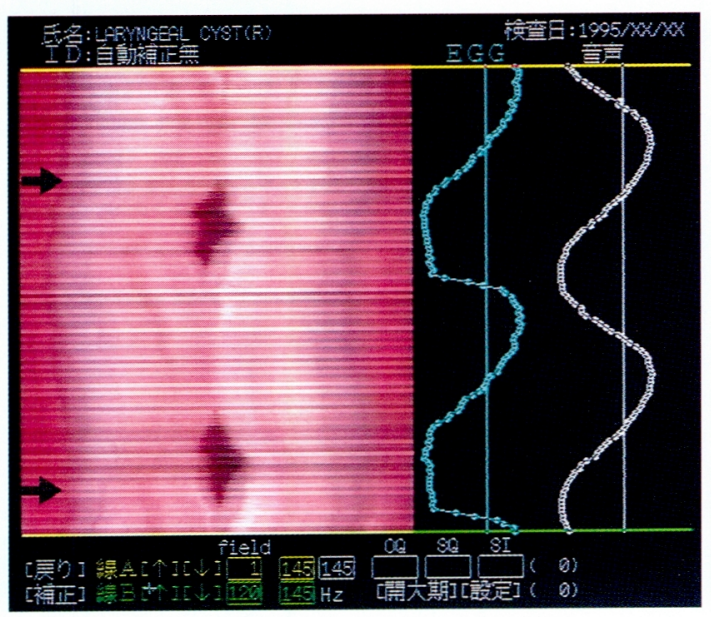

図 6 喉頭鏡の手ぶれが大きい振動周期のストロボグ ラム. 左欄の声带振動画像は, 動画再生では振 動していない仮声带と声带との境界部 $(\rightarrow)$ が 手ぶれによって正弦波状に摇れてしまっている.

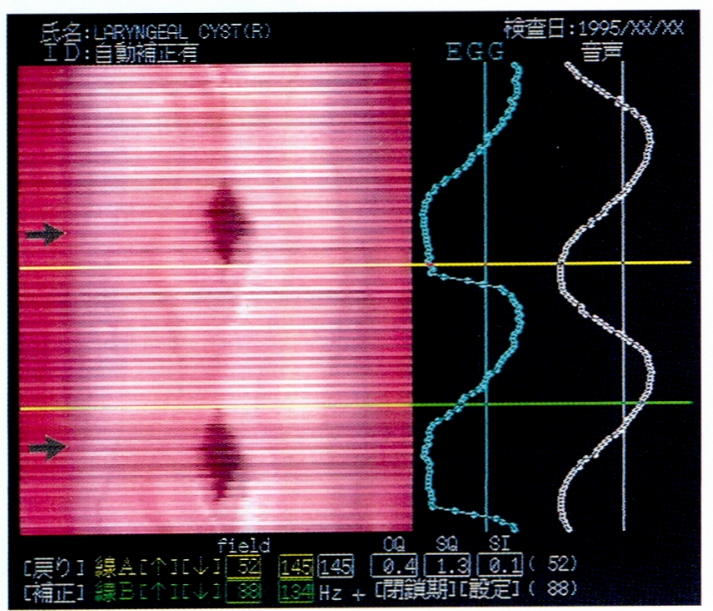

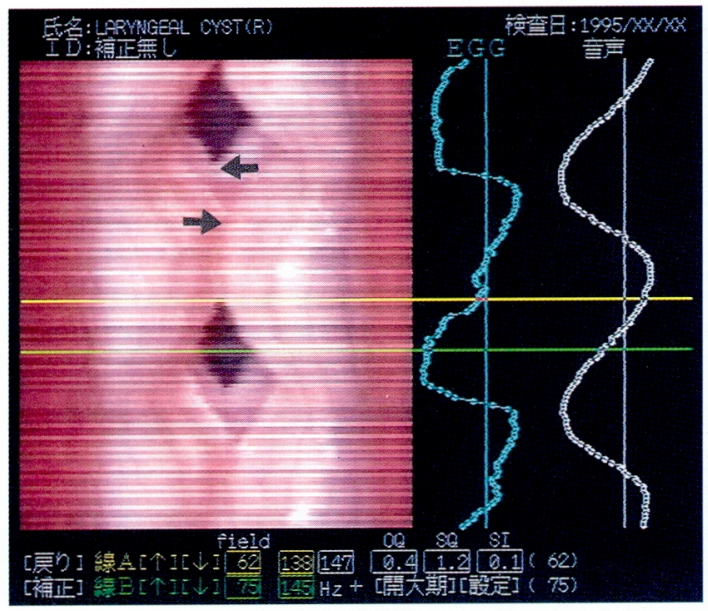

図3図2 の喉頭ストロボグラム。左欄は声帯振動像, 中央は EGG 波形，右欄は音声波形。黄色線 (線 A) と緑色線（線 B ）は解析フィールド指 定カーソル。

画面最下段の線 $\mathrm{A}$, 線 $\mathrm{B}$ の右隣の数值は各線の 位置するフィールド番号，その右隣は両フィ ルドに同期した音声基本周波数, その右隣は, 両フィールド間の平均基本周波数，その右隣は 開閉運動のパラメータの $\mathrm{OQ}, \mathrm{SQ}, \mathrm{SI}$.

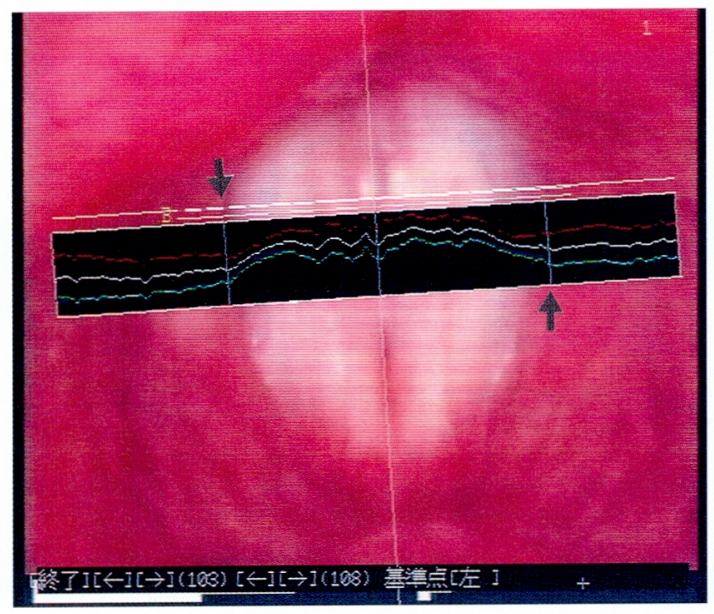

図 7 図 6 の第1フィールド画像の解析軸上の輝度信 号分布：R (赤色), G (緑色), B (青色), W (白色) $(2 \mathrm{R}+\mathrm{G}+\mathrm{B} / 4)$. 左側（】）と右 側（†）の非振動部分（ノッチ）の位置と, 基 準とする側（この場合は左側）を指定する。
図8図 7 を自動補正した結果. 左端の非振動部分 $(\rightarrow$. 仮声帯と声带との境界部) が縦に一列に 並んで自動補正されている。 


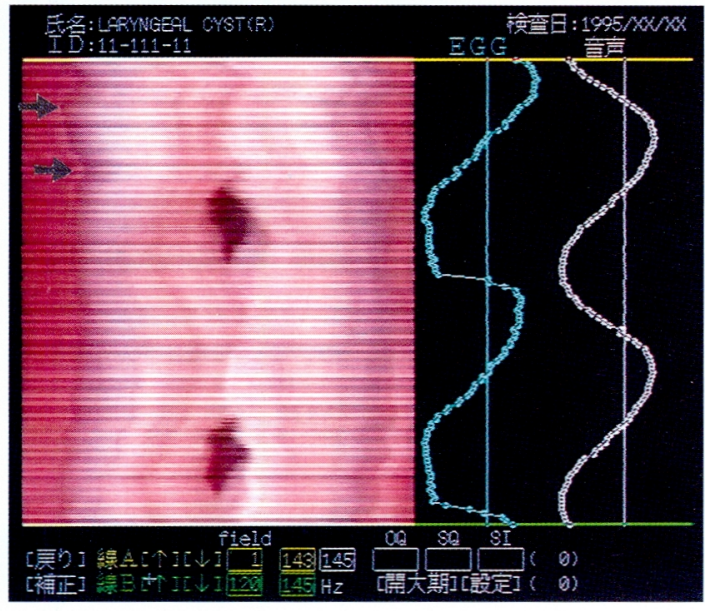

図 9 図 6 とは異なる振動周期の, 解析軸の補正無し のストロボグラム．左端の非振動部分 $(\rightarrow$. 仮 声帯と声帯との境界部）が手ぶれによって不規 則に摇らいでいる。

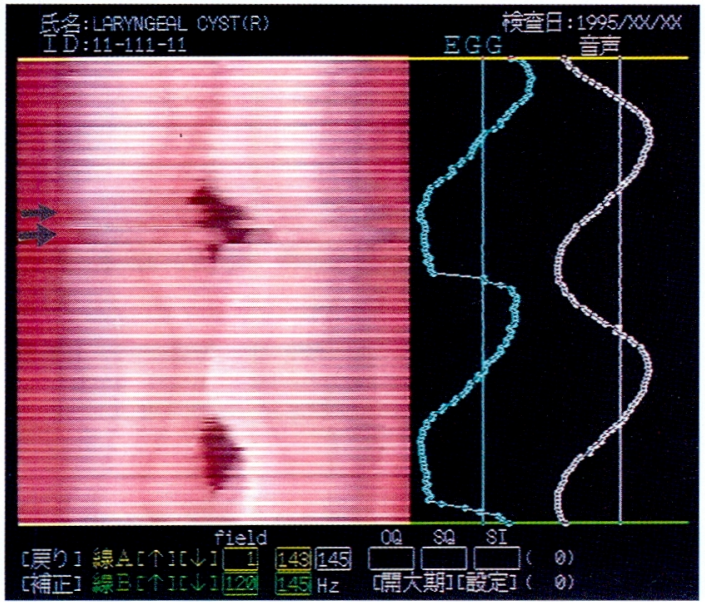

図11図9の自動補正の結果. 非振動部が一部（ $\rightarrow$ で誤認されてしまっている。

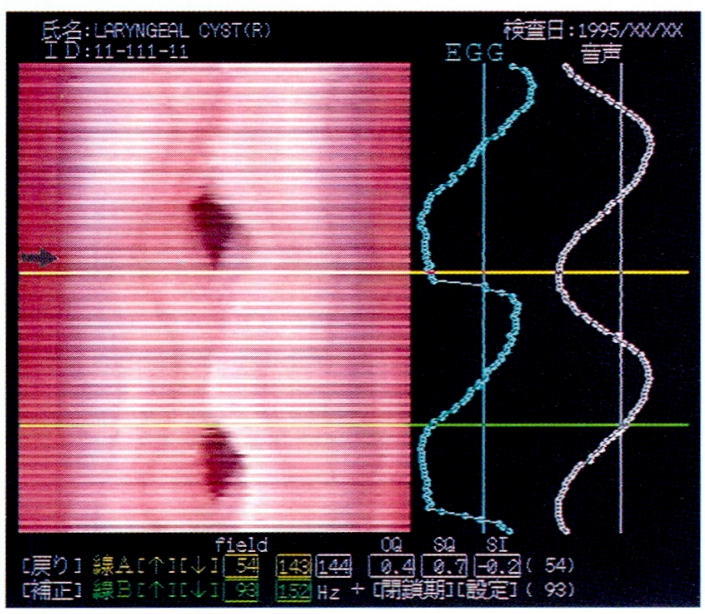

図13図12で誤認された非振動部が基準点の位置 $(\rightarrow)$ に適正に補正されている.

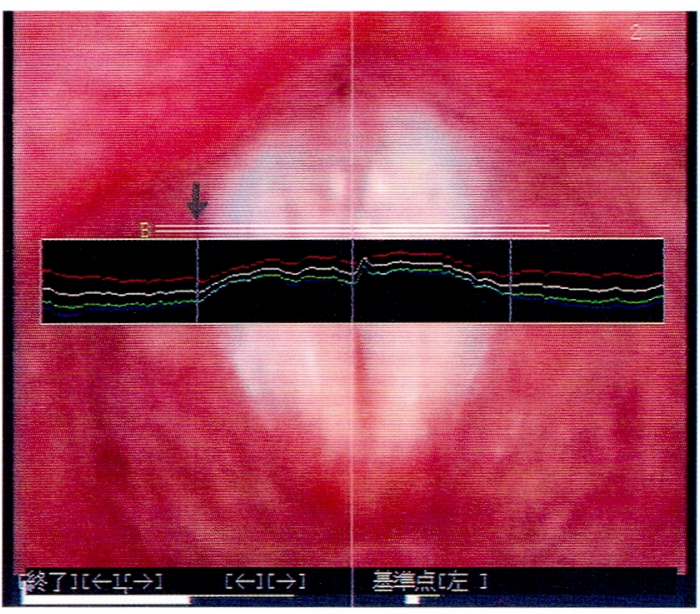

図10 図9のフィールド画像の解析軸上の輝度信号分 布波形、基準とした左側のノッチ（】）の振幅 が極めて小さい

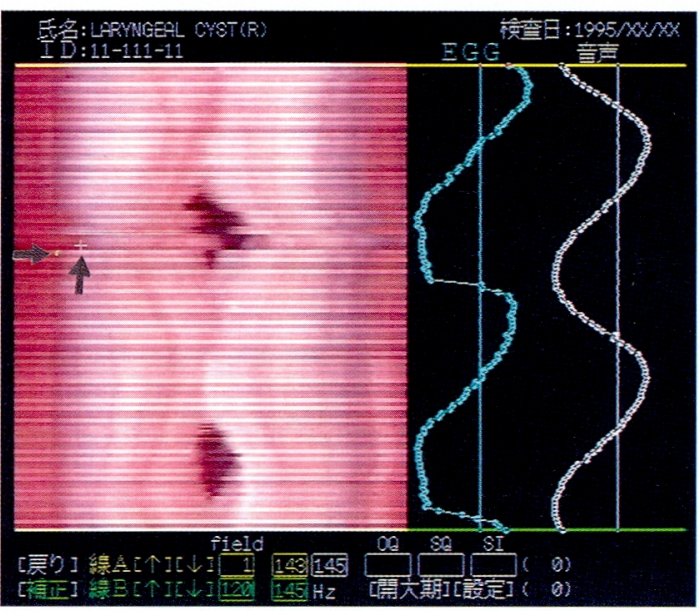

図12 目認 (手動) による図11の簡単な追加補正法。非 振動部分の位置（ $\rightarrow$ の白点部）を基準点として指 定し,この位置に一致させるべき別のフィールド の位置 (†の十記号部) を指定すると, 十の位置 を基準点の白点部の位置まで自動的に移動する。

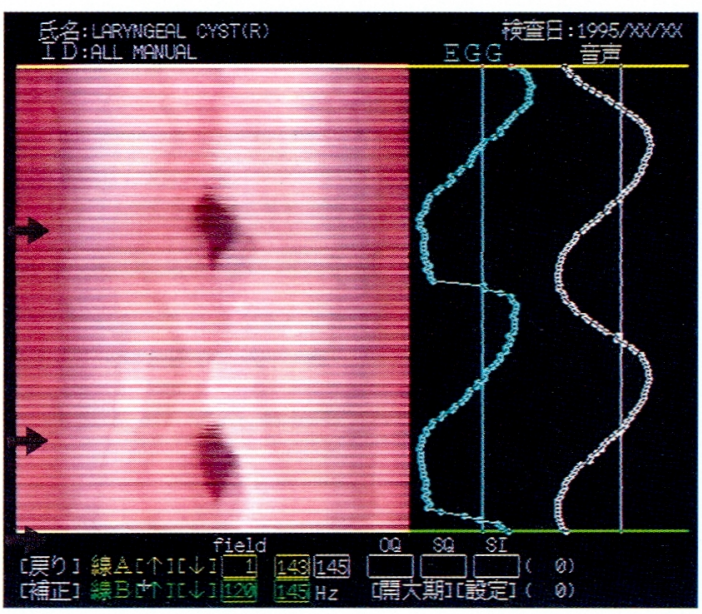

図14四9を,全周期にわたって完全に手動（マニュ アル) で解析軸の補正を行った結果。（（は仮 声帯と声带の境界部) 